\title{
Paternity in Brazilian goats through the use of DNA microsatellites
}

\author{
Adriana Mello de Araújo ${ }^{1,2}$, Simone Eliza Facioni Guimarães ${ }^{1}$, Carmen Silva Pereira ${ }^{1}$, Paulo \\ Sávio Lopes ${ }^{1}$, Marcelo Teixeira Rodrigues ${ }^{1}$, Théa Mírian Medeiros Machado ${ }^{1}$
}

\footnotetext{
${ }^{1}$ Laboratório de Biotecnologia Animal, Departamento de Zootecnia, Universidade Federal de Viçosa, MG.

${ }^{2}$ Embrapa Meio-Norte, Teresina, PI.
}

ABSTRACT - A total of 292 animals from three breeds (Alpine and Saanen dairy breeds, and the Brazilian naturalized breed Moxotó) were genotyped, comprising 276 paternity cases. Statistical analyses were carried out by using TFPGA and CERVUS programs. Heterozygosis ranged from 0.542 (ILSTS005) to 0.825 (INRA006), with an average of 0.717 for all loci. Polymorphic information content (PIC) was 0.676 and 0.542, and combined exclusion probabilities (EP) were 0.999591 and 0.988375 for known and unknown maternal genotypes, respectively. The microsatellite system reveals $10 \%$ of paternity misidentification in evaluated registers.

Key Words: Brazil, local breed, paternity exclusion, pedigree mismatching, polymorphism

\section{Paternidade em caprinos por meio de microssatélites de DNA}

\begin{abstract}
RESUMO - Um total de 292 animais de três raças (leiteiras Alpina e Saanen e a raça brasileira naturalizada Moxotó) foram genotipados, compreendendo 276 casos de paternidade. As análises estatísticas foram realizadas nos programas TFPGA e CERVUS. A heterozigosidade esperada variou de 0,542 (ILSTS005) a 0,825 (INRA006), com média de 0,717 para todos os loci. O conteúdo de informação polimórfica (Polymorphic information content, PIC) para todos os loci, foi de 0,676 e 0,542 e a probabilidade de exclusão (EP), de 0,999591 e 0,988375 para casos em que o genótipo materno era conhecido e desconhecido, respectivamente. A taxa de erro de identificação de paternidade é de $10 \%$ nos registros avaliados.
\end{abstract}

Palavras-chave: Brasil, erro de pedigree, exclusão de paternidade, polimorfismo, raça naturalizada

\section{Introduction}

Goats are the most widely spread domestic species in the world and play an important economical role in developing countries. Brazil has the tenth largest world goat herd with about ten million animals (IBGE, 2006). In Brazil, goat breeding ranges from an intensive system in the dairy basins in the southern and southeastern regions to an extensive raising system at the Northeast region, where a large number of herds is found, contributing to sustainable small scale agriculture. Goat genetic resources are very diverse, with foreign European breeds like Alpine and Saanen being the most important resources for dairy production. On the other hand, at the Northeast region, a large number of herds has no defined breed, or is composed by naturalized groups, such as Moxotó, Canindé, Marota, and Repartida (Machado, 2000).

There isn't an official National Genetic Goat Improvement Program in Brazil. Genealogical data are registered at the Associação Brasileira de Criadores de Caprinos (ABCC) and its branches. The few initiatives to create a goat database are isolated efforts of breeders and research institutions without substantial results. All breeding programs are based on non official information and considering the losses on selection accuracy and on genetic gain generated by genealogical misidentification the need for a correct paternal identification is a major concern for the evaluation of genetic parameters and the success of breeding programs.

Statistical methods for pedigree checking in natural populations or those on which data are taken on a large scale may differ in focus from commercial laboratories, whose goal is to confirm genetic compatibility of the alleged father, mother and progeny trio using parentage exclusion. The goal of the present study is to use eleven microsatellites loci to solve genealogy and to verify the accuracy of the registered pedigrees in Brazilian goat herds. 


\section{Material and Methods}

Pedigree register for 121 Alpine and 94 Saanen goats from Universidade Federal de Viçosa, 36 Alpine and 19 Saanen goats from a private herd, and 22 Moxotó goats from preservation herd of Embrapa, were analyzed. Samples were distributed in existing sire families of each herd to obtain a progeny group for each male breeding stock. Known mothers were genotyped within the herd.

For Alpine and Saanen breeds, blood was collected from the jugular vein, using a vacuum system, and stored at $4^{\circ} \mathrm{C}$ for $6 \mathrm{~h}$. DNA was extracted by following the phenol: chloroform protocol (Sambrook et al., 1989). DNA samples from the Moxotó herd were obtained from hair follicles, following the cetiltrimetilammonium bromide protocol, as described by Ferreira \& Grataplagia (1998).

The following loci were tested: BETACAP, INRA005, ILSTS087, INRA006, INRA063, INRABERN172, ILSTS005, ILSTS011, SRCRSP05, OARFCB48, and BM3205 (Table 1). The BETACAP locus belongs to the casein gene cluster (Pépin et al., 1995). INRA005, ILSTS0087, INRA006, INRA063, INRABERN172, ILSTS005, ILSTS011, and $B M 3205$ loci in goats are homologous to cattle, and the OARFCB48 locus is homologous to sheep (Vaiman et al., 1996). Arevalo et al. (1994) described the SRCRSP005 locus in goats. The primer sequence of these loci can be accessed in GOATMAP DATABASE (http://locus.jouy.inra.fr).

Each $20 \mu \mathrm{l}$ PCR reaction contained $25 \eta \mathrm{g}$ DNA, $20 \mathrm{mM}$ Tris-HCl (pH 8.3), $50 \mathrm{mM} \mathrm{KCl,} 0.2 \mathrm{mM}$ each dNTP, $1.25 \mathrm{mM}$ to $2.5 \mathrm{mM} \mathrm{MgCl}_{2}$, and $1 \mathrm{U}$ Taq DNA polymerase. For each one of the different loci, primer concentrations were adjusted between $0.12 \mu \mathrm{M}$ and $0.20 \mu \mathrm{M}$. The denaturation step of $94^{\circ} \mathrm{C} / 3$ min was followed by 27 cycles at $94^{\circ} \mathrm{C} / 1 \mathrm{~min}$, annealing temperature according to each primer pair $/ 1 \mathrm{~min}, 72^{\circ} \mathrm{C} / 1 \mathrm{~min}$, and a final extension of $72^{\circ} \mathrm{C} / 20 \mathrm{~min}$.

Reverse primers were fluorescently labeled with Tet, 6-Fam, and Hex dyes, so amplified fragments did not overlap, and multiplexed electrophoresis could be used. Amplified fragments were submitted to capillary electrophoresis at $9 \mathrm{~V}, 60^{\circ} \mathrm{C}$ for 22 minutes and analyzed with ABI 310 Genetic Analyzer from Applied Biosystem ${ }^{\mathrm{TM}}$, utilizing Genescan ${ }^{\circledR}$ software (Table 1).

Gene frequencies were obtained for each allele by direct count. The polymorphic information content was used to quantify polymorphism when one progenitor genotype was know (PIC 1 ) (Bolstein et al., 1980) and when both progenitors genotypes were unknown $\left(\mathrm{PIC}_{2}\right)(\mathrm{Da} \&$ Lewin, 1995).

Exclusion probability was calculated with TFPGA software (Miller, 1997), firstly for cases in which one progenitor was confirmed, and genotypes were known for the alleged father, mother and progeny $\left(\mathrm{EP}_{1}\right)$, and secondly when just the father and progeny genotypes were known $\left(\mathrm{EP}_{2}\right)$ (Jamieson \& Taylor, 1997).

The maximum likelihood method by the CERVUS program (Marshall et al., 1998) was applied to check pedigree mismatching. CERVUS program is used to calculate allelic frequencies in a simulation approach and to determine the confidence in parentage assignments by calculating critical values of the log likelihood statistics $\Delta$ (Delta).

The exact test of Hardy-Weinberg proportion was performed by TFPGA software (Miller, 1997), using the method developed by Guo and Thompson (1992) of Markov Chain (10 batches, 5.000 permutations, and 1.000 dememorization steps).

Table 1 - Locus, chromosome localization, annealing temperature, $\mathrm{MgCl}_{2}$ concentration, primer concentration, dye, number of alleles observed, and allele size

\begin{tabular}{|c|c|c|c|c|c|c|c|}
\hline Locus & Chromosome & $\begin{array}{c}\text { Annealing } \\
\text { temperature } \\
\left({ }^{\circ} \mathrm{C}\right)\end{array}$ & $\begin{array}{c}\mathrm{MgCl}_{2} \\
\text { concentration } \\
(\mathrm{mM})\end{array}$ & $\begin{array}{c}\text { Primer } \\
\text { concentration } \\
(\mu \mathrm{M})\end{array}$ & Dye & $\begin{array}{l}\text { Number of } \\
\text { alleles observed }\end{array}$ & $\begin{array}{c}\text { Allele Size } \\
\text { (pb) }\end{array}$ \\
\hline INRA005 & 12 & 55 & 1.25 & 0.16 & 6-Fam & 5 & $113-121$ \\
\hline ILSTS0087 & $\mathrm{n}$ & 55 & 1.25 & 0.12 & 6-Fam & 9 & $135-153$ \\
\hline INRA006 & 3 & 55 & 2.50 & 0.16 & Hex & 10 & $106-126$ \\
\hline INRA063 & 18 & 56 & 2.0 & 0.20 & 6-Fam & 7 & $162-207$ \\
\hline ILSTS011 & 14 & 56 & 2.0 & 0.16 & 6-Fam & 10 & $262-280$ \\
\hline SRCRSP05 & 21 & 56 & 2.0 & 0.16 & Hex & 7 & $157-173$ \\
\hline OARFCB48 & 17 & 58 & 3.0 & 0.20 & Tet & 7 & $152-164$ \\
\hline BM3205 & 1 & 50 & 1.25 & 0.20 & Hex & 11 & $215-237$ \\
\hline
\end{tabular}

n locus no genetic or RH mapped. 


\section{Results and Discussion}

Expected average heterozygosity (HE) was 0.717, ranging from 0.542 (ILSTS005) to 0.825 (INRA006). As expected, polymorphic information content was greater for loci with greater heterozygosity (INRA006). Mean allele number per locus was 7.18 for Alpine and Saanen breeds and 3.5 for the Moxotó breed.

The polymorphic information content (when one progenitor genotype was known and when both progenitor genotypes were unknown), and the probability of combined exclusion were 0.676 and 0.5420 ; and 0.999591 and 0.988375 , respectively, when the maternal genotype is known or not (Table 2). In goats, Luikart et al. (1999) developed a panel with 22 microssatelites in two multiplex reactions to test paternity and obtained an exclusion probability >0.99999. In Brazil, Curi \& Lopes (2002) achieved a combined exclusion probability of 0.9789 with nine bovine microssatelite loci. These obtained exclusion probabilities must be improved by more loci to attend the paternity test. However, the microsatellites tested are informative by scan registers errors and quantified some noise in genetic evaluation in Brazil.

The chosen loci are independent, located on distinct chromosomes and have simple Mendelian inheritance. Exclusion of the panel was similar to that proposed by Luikart et al. (1999) for the Saanen breed in Switzerland. BETACAP, INRA005, ILSTSO05, and SRCRSP05 loci are moderately polymorphic $\left(\mathrm{H}_{\mathrm{E}}>0.70\right)$ as considered by Ott (1992). Removal of each one of the above loci decreased exclusion probability for unknown mother genotype respectively to $0.9846,0.9854,0.9862$, and 0.9835 . Removal of all four loci decreased exclusion probability for unknown mother genotype to 0.9676 .

Twenty-seven father-progeny genotypes had at least three mismatching genotypes which were considered as register errors in the paternity exclusion test corresponding to approximately $10 \%$ of the total. Additionally, 39 cases remained unsolved by the exclusion approach (with 1-3 supposed father-progeny incompatibilities). In these remaining cases, either the alleged father could have been rejected as the real father or other statistical proxies can be used (Marshal et al., 1998).

Paternity register error in the present study was close to $10 \%$, which is similar to the rates in European cattle dairy breeds (Ron et al., 1996). In Brazil, Rosa et al. (1997) obtained approximately 15\% error in Nelore cattle, and Curi and Lopes (2002) observed 27.5\% error in Gir families registered in the herd book of Associação Brasileira dos Criadores de Zebu (ABCZ).

Significant deviations $(\mathrm{p}<0.01)$ from Hardy-Weinberg balance were verified for INRA063 and OARFCB48 loci in all breeds, and it is the same loci responsible for the greatest number of genotyping mismatches with frequencies of 0.1571 and 0.080 , respectively.

The deviation of the Hardy-Weinberg verified in this study for some loci can be caused due to sampling (Wahlund effect), having to reach the balance when more flocks are used (Luikart et al., 1999). Null alleles were verified for INRA063 and OARFCB48 loci, leading to a deficit of observed heterozygote. Null or non-amplified alleles could also be the reason for the Hardy-Weinberg inbalance.

Table 2 - Number of observation, expected heterozygosity, polymorphic information content and exclusion probability for all loci under study

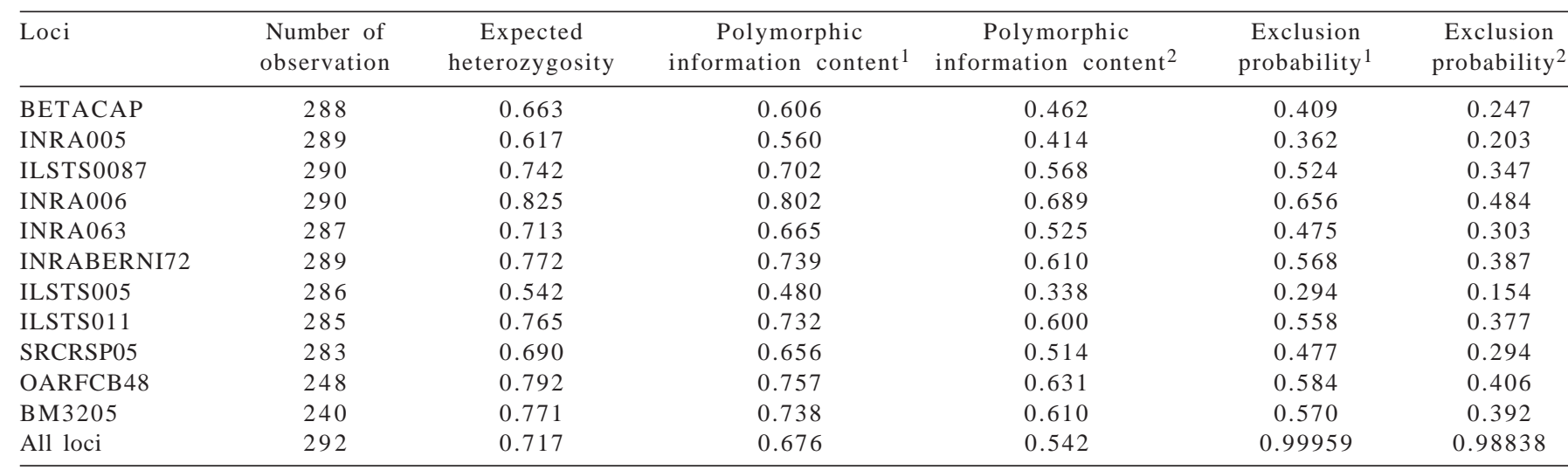

\footnotetext{
${ }^{1}$ Genotype of the mother was known.
}

${ }^{2}$ Genotype of mother was unknown. 


\section{Conclusions}

The eleven microssatelite loci compose a panel able to check accurately pedigrees. Knowledge of the maternal genotype greatly increases test accuracy, thus whenever it is possible, genotype of the dam has to be accessed. Modifications made over time may be implemented to incorporate other loci to improve exclusion probability, especially when the maternal genotype is unknown.

\section{References}

AREVALO, E.; HOLDER, D.S.; DERR, J.N. et al. Goat microsatellite dinucleotide repeat polymorphisms at the SR-CRSP 1, 2, 3, 4 and 5 loci. Animal Genetics, v.25, p.202, 1994.

BOLSTEIN, D.; WHITE, R.L.; SKOLNICK, M. et al. Construction of genetic linkage map in man using restriction fragment length polymorphism. American Journal of Human Genetics, v.32, p.314-331, 1980.

CURI, R.A.; LOPES, C.R. Evaluation of nine microsatellite loci and misidentification paternity frequency in a population of Gyr breed bovines. Brazilian Journal of Veterinary Research Animal Science, v.39, p.129-135, 2002.

DA, Y.; LEWIN H. A. Linkage information content and efficiency of full-sib and half-sib designs for gene mapping. Theoretical and Applied Genetics, v.90, p.699-706, 1995.

GUO, S.W.; THOMPSON, E.A. Performing the exact test of HardyWeinberg proportion for multiple alleles. Biometrics, v.48, p.361-372, 1992.

INSTITUTO BRASILEIRO DE GEOGRAFIA E ESTATÍSTICA IBGE. Censo Agropecuário de 2001. Disponível em: <http:// www.ibge.org.br> Acesso em: 20/1/2004.

JAMIESON, A.; TAYLOR, ST. C.S. Comparisons of three probability formulae for parentage exclusion. Animal Genetics, v.28, p.397-400, 1997.
FERREIRA, M.A.; GRATTAPAGLIA, D. Introdução ao uso de marcadores moleculares em análise genética. 3.ed. Brasília: Embrapa Cenargen,1998. p.220.

LUIKART, G.; BIJU-DUVAL, M-P.; ERTUGRUL, O. et al. Power of 22 microssatelite markers in fluorescent multiplexes for parentage testing in goats (Capra hircus). Animal Genetics, v.30, p.431-438, 1999

MACHADO, T.M.M. Caprins autochtones du Brésil: L'identication, la standardisation et la savergarde. In: INTERNATIONAL CONFERENCE ON GOATS, 7., 2000, Tours. Proceedings... INRA, 2000. v.2, p.941-943.

MARSHALL, T.C.; SLATE, J.; KRUUK, L.E.B. et al. Statistical confidence for likelihood-based paternity inference in natural populations. Molecular Ecology, v.7, p.639-655, 1998.

MILLER, M.P. [1997]. TFPGA- Tools for populations genetics analyses. V 1.3 A Window program for the analysis of allozyme and molecular population genetic data. Disponível em: <http://herb.bio.nau.edul miller/tfpga.htm> Acesso em: $20 / 11 / 2005$.

OTT, J. Strategies for characterizing highly polymorphic markers in human gene mapping. American Journal of Human Genetics, v.51, p.283-290, 1992.

PEPIN, L.; AMIGUES, Y.; LEPINGGLE, A. et al. Sequence conservation of microsatellites between cattle, goat and related species. Heredity, v.74, p.53-61, 1995.

ROSA, A.J.M.; PACKER, I. U.; REGITANO, L.C.A. Caracterização da raça Nelore e teste de paternidade por marcadores moleculares. In: REUNIÃO ANUAL DA SOCIEDADE BRASILEIRA DE ZOOTECNIA, 34., 1997, Juiz de Fora. Anais... Juiz de Fora: Embrapa, 1997. v.3, p.62-64.

RON, M.; BLANC, Y.; BAND, M. et al. Misidentification rate in Israeli dairy cattle population and its implications for genetic improvment. Journal of Dairy Science, v.79, p.676-681, 1996.

SAMBROOK, J.; FRITSCH, E.F.; MANIATS, T. Molecular cloning: a laboratory manual. 2.ed. New York: Cold Spring Harbor Lab, 1989. 479p.

VAIMAN, D.; SCHIBLER, L.; BOURGEOIS, F. et al. A genetic linkage map of the male goat genome. Genetics, v.144, p.279-305, 1996. 